\title{
Problems of Social Adaptation of Bachelor's Degree Students of Pedagogical Field under the Conditions of examine in Agrarian University
}

\author{
N. N. Nikulina, I. V. Gordienko, I. A. Belozerova, N. I. Lyubimova, M. G. Davityan \\ (Belgorod, Russia)
}

\begin{abstract}
Problem and objective. Nowadays, in the practice of training of professional educational organizations there is a discrepancy between the methods of training acceptable at the basic school and the university, which complicates the process of adaptation of students to the new conditions. The social status of a "student", a large amount of information, lack of skills of independent work, reduced control over educational activities by both parents and teachers, requires the student to mobilize available resources and opportunities for successful adaptation in the university. At this stage of personal development, various forms of disadaptation behavior may appearTraining of students of pedagogical orientation in the walls of a non-core university is associated with additional problems, which, above all, consist in the emerging contradictions between the humanitarian and nonhumanitarian orientation of the learning process. The purpose of the research presented in the paper is to analyze the process of adaptation of bachelor students of pedagogical field to the conditions of training in an agrarian university and to determine the main directions of its improvement. Proposed Methodology. Methodological grounds for the study of the problem of social adaptation of bachelor students of pedagogical field in a noncore university were: analysis; comparison; typologization of theoretical sources; diagnostic methods that allowed to carry out theoretical and methodological substantiation of the essence and specificity of adaptation of students to training in a non-core university.The sociological toolkit of the questionnaire survey included the test methodology of $K$.
\end{abstract}

\section{Revised Manuscript Received on December 30, 2019.}

* Correspondence Author

Nikulina Natal'ya Nikolaevna, Associate Professor, Department of Professional Education and Social and Pedagogical Disciplines, Federal State Budgetary Educational Institution of Higher Education Belgorod State Agricultural Univerisity named after V. Gorin.

E-mail: nikulina_nn@bsaa.edu.ru

Gordienko Irina Vladimirovna, Associate Professor, Department of Professional Education and Social and Pedagogical Disciplines, Federal State Budgetary Educational Institution of Higher Education Belgorod State Agricultural Univerisity named after V. Gorin.

E-mail:: girina@mail.ru

Belozerova Irina Aleksandrovna, Associate Professor, Department of Professional Education and Social and Pedagogical Disciplines, Federal State Budgetary Educational Institution of Higher Education Belgorod State Agricultural Univerisity named after V. Gorin. E-mail: irina_belozerova1965@mail.ru

Lyubimova Natal'ya Ivanovna, Associate Professor, Department of Professional Education and Social and Pedagogical Disciplines, Federal State Budgetary Educational Institution of Higher Education Belgorod State Agricultural Univerisity named after V. Gorin. E-mail: lybimova.1979@mail.ru

Davityan Manushak Galustovna, Associate Professor, Department of Professional Education and Social and Pedagogical Disciplines, Federal State Budgetary Educational Institution of Higher Education Belgorod State Agricultural Univerisity named after V. Gorin. E-mail: 79611729056@yandex.ru

(C) The Authors. Published by Blue Eyes Intelligence Engineering and Sciences Publication (BEIESP). This is an open access article under the CC BY-NC-ND license (http://creativecommons.org/licenses/by-nc-nd/4.0/)
Rogers and R. Diamond, formulas of Rylon, SpearmanBrown, Cronbach. For processing the answers of respondents (n $=210$ ) the methods of mathematical statistics - correlation and cluster types of analysis - were used. Results. The authors have revealed general and specific features of the adaptation process of students of pedagogical field in the conditions of training of non-core higher education institution; comparative analysis of social-psychological and social-professional adaptation of students has been carried out; the most acute problems and difficulties of social-professional adaptation have been revealed; criteria and levels of adaptation of students of pedagogical orientation have been formed; proposals on improvement of the process of adaptation of students of pedagogical orientation have been developed and applied in practice.

Conclusion. The conducted research allowed to get a comprehensive idea about the organization of the adaptation process of future teachers to the conditions of training in a noncore higher education institution. The materials of the study can be used in the management of the adaptation process in higher education, including the educational and leisure activities of curators of student groups, teachers, psychologists and educators in dormitories.

Keywords: social environment, adaptation, disadaptation, educational process, educational activity, adaptation factors, adaptation criteria, monitoring of the adaptation process.

\section{INTRODUCTION}

Studying the problem of adaptation of bachelor students and finding ways to optimize it at the socio-psychological and socio-professional levels is an extremely important issue for higher education, and above all, for the training of future teachers in non-core universities.

Today, in the practice of training of professional educational organizations there is a discrepancy between the methods of training used in basic schools and universities, which complicates the process of adaptation of students to the new conditions. The social status of a "student", a large amount of information, lack of skills of independent work, reduced control over educational activities by both parents and teachers require the student to mobilize available resources and opportunities for successful adaptation in the university. At this stage of personal development, various forms of disadaptation behavior may appear.

Agrarian education is the leading one in Federal State Budgetary Educational Institution of Higher Education Belgorod State Agricultural Univerisity named after V. Gorin. The main emphasis is placed on the acquisition of a complex of knowledge, skills and competencies of various levels, allowing students to successfully carry out professional activities in the production, processing and sale of agricultural products in the future.

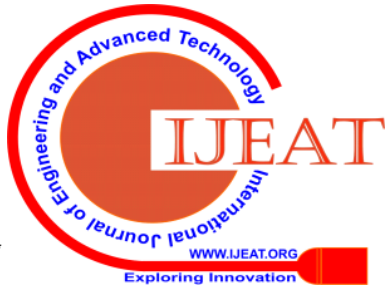


Education of students of pedagogical field within a noncore university is associated with additional problems,

which, first of all, consist in emerging contradictions between the humanitarian and non-humanitarian orientation of the learning process: firstly, in the process of education of future teachers in a non-core university organizational and communicative abilities are not sufficiently formed; secondly, the majority of teachers and curators do not have basic pedagogical education, they do not pay due attention to the organization of education; thirdly, from the first year onwards, students study technical and agricultural disciplines that are not focused on the formation of pedagogical competencies.

The objective of this article is to analyze the process of adaptation of bachelor students of pedagogical field to the conditions of training in an agrarian university and to determine the main directions of its improvement.

\section{REVIEW CRITERIA}

The problem of social and socio-psychological adaptation is presented in the works of Y.A. Svechnikov and A.I. Khaustov [34; 37]. The analysis of the key problems of the process of socialization, professional education and selfdetermination is presented in the works of the leading specialists in adaptation processes M.V. Romm, T.A. Romm, M.V. Rostovtseva [31-33].

The peculiarities of psychological adaptation to the conditions of education in universities are reflected in the research of E.P. Alexandrov, T.G. Anisimova, M.V. Vorontsova and others. [11; 12; 15; 21; 23].

Problems of adaptation of students in professional educational institutions of secondary and higher education are reflected in scientific and practical research by I.V. Gordienko, N.I. Lyubimova, N.N. Nikulina [16; 17; 28-30; 13; 14; 36]. The works of I.A. Belozerova, M.G. Davityan, E.V. Krikun present a psychological and sociological portrait of a person in the conditions of adaptation to student life [18-20; 24-26].

The problem of socio-psychological and socioprofessional adaptation is traced in foreign sources of authorship (M.O. Amponsah, M.J. Mayhew et al.) [1-10].

Measures to improve the effectiveness of the social adaptation of young people, including students, are reflected in federal and regional legislation. In particular, the Federal Law "On Education in the Russian Federation" provides for a system of measures to provide social support and incentives for students aimed at creating favourable conditions for the successful socialization and adaptation of students in society. The resolutions of the Government of the Belgorod Region "On Approval of the State Program "Development of Education of the Belgorod Region for 2014-2020" reflect the issues of improving the efficiency of management of the adaptation process through the "creation of legal, socio-economic and organizational conditions for self-realization, social development of young people, their implementation of constitutional rights and obligations.

The above-mentioned studies investigate various aspects of the adaptation process of student youth, but do not reveal the specifics of adaptation of students of pedagogical field to the conditions of study in an agrarian university.

\section{PROPOSED METHODOLOGY}

The methodological foundations of the research were: analysis, comparison, typologization of theoretical sources (special literature, normative-legal and periodicals); diagnostic methods (observation, polling, including questionnaires, pedagogical analysis), which made it possible to carry out theoretical-methodological substantiation of the essence and specificity of students' adaptation to the study at the university.

To identify the effectiveness of the process of adaptation of bachelor students of pedagogicalfield, the authors have conducted an experimental study among students of the first year of study 44.03.04 Professional training (2017 - 2019). The total sample size was 210 respondents.

The sociological toolkit of the questionnaire survey to identify the degree of adaptation of the student to the educational activities and to the student group included a test methodology of diagnostics of socio-psychological adaptation of K. Rogers and R. Diamond. Verification of the reliability of the data obtained was carried out using the method of "splitting" and the subsequent calculation of the corresponding coefficients. In order to determine the accuracy and reliability on both scales, the Rylon formula was used; the calculation of reliability-coordination coefficients was made using the Spearman-Brown formula and the Cronbach formula.

In order to study adaptation processes, the study used its own questionnaires, which are not standardized questionnaires.

\section{RESULT ANALYSIS}

The research on the problems of adaptation of bachelor students of pedagogical orientation was carried out on the basis of determination of the indicator of success of the adaptation process, the main criterion of which was the degree of adaptation (high, medium, low) of freshmen to the university.

\section{A. Abbreviations}

VUZ - a higher education institution, FGBOU VO Belgorod GAU - Federal State Budgetary Educational Institution of Higher Education Belgorod State Agricultural Univerisity named after V. Gorin.

\section{B. Units of measurement}

The integrated total adaptation was calculated as a sum of average statistical values for all adaptation indicators analysed below:

1) satisfaction with educational activities ("yes", "no", "50/50");

2) satisfaction with the team: peculiarities of the emotional state ("stable"/"unstable" emotional background);

3) the level of motivation for educational activity ("high", "medium", "low");

4) adaptation of the student to the learning activity and adaptation of the student to the group.

For the survey the students were selected of the Faculty of Economics of pedagogical field 44.03.04. Professional training (by industry). 


\section{Formulas}

We consider satisfaction with the learning process as one of the conditions for successful adaptation of students to the university.

To this end, students were asked the question: "Do you get satisfaction from studying at the university? Of the total number of surveyed students, the majority (57.9\%) replied "Yes", 9.6\% of respondents - "No", 32.5\% - found it difficult to answer. The index of satisfaction with studying, calculated by us as a contrast index according to formula 1 , was $I_{k}=0.48$, which indicates the average level of satisfaction with studying.

$I_{k}=(\mathrm{a}-\mathrm{b}) / 100$,

where $\quad \mathrm{a}$ and $\mathrm{b}$ - polar response rate,

100 - constant value used for the convenience of calculation.

The question about satisfaction with studies was supplemented by the question "How do you assess the start of your studies at university? $57.4 \%$ of students said that "they like their studies and they study well". $14.4 \%$ of the survey participants noted that " they have started to study worse at the university than at school", $11.5 \%$ of respondents feel confused: they have no clear idea about the nature of the social role of the student. $9.5 \%$ of those who responded to the survey found it very difficult to do so. Only $7.2 \%$ of students did not notice a big difference between studying at the university and at school.

In order to determine the level of satisfaction with the team and its relations, a special question was provided in the structure of the questionnaire: "How are the relationships in the group? $55.5 \%$ of respondents believe that "the student group in which they study is friendly and close-knit"; $29.7 \%$ of respondents indicated that "the group is divided into subgroups"; $11.1 \%$ of students believe that "the group is not formed yet"; $3.7 \%$ of respondents "feel lonely in the group". The index of the level of satisfaction with the group and its relations was calculated according to the formula 2, with the assignment of the indicator "close-knit and friendly group" 1.0, "the group is divided into subgroups" - 0.5, "the group is not formed yet" - 0.5, "I feel lonely in the group" - 1:

(2)

$$
K_{y}=K_{1} * r_{1}+\ldots+K_{4} * r_{4} \text {, }
$$

where $K_{i}-\mathrm{i}$-th division of the scale weight,

$r_{i}$ - the percentage of selection of the i-th division of the scale,

and can be characterized as above average $\left(K_{y}=0,61\right)$.

Let's consider the following criterion of students' adaptation to the university life - the level of motivation to educational activity. The overwhelming majority of the surveyed students (67.4\%) call "the desire to study in the chosen profession" the main motive of education. This group of students consciously made their professional choice and is satisfied with the process of studying at this university. Nevertheless, more than a quarter of the surveyed students (26.1\%) believe that the main motive for learning is "because it is necessary"; $5.0 \%$ of respondents study "because it is the desire of parents, and they can't let them down"; $1.5 \%$ of students chose to study at the university as "an opportunity to get a legal deferral from the army".

The level of motivation of students to study is characterized by the choice of leisure time in their free time. For $59.6 \%$ of the surveyed students the choice was made in the direction of passive leisure activities. The majority of respondents
(33.8\%) devote their free time to household chores. Other students (15.2\%) read books and watch TV. $10.6 \%$ of respondents stay at home and do nothing. Out of $40.4 \%$ of the students who chose active leisure activities, 29.4\% attend circles, sections, clubs; $11.0 \%$ - entertainment establishments (cinemas, theatres, discotheques, bars). From our point of view, the predominance of passive leisure activities in higher education indicates the transition character of students who have not yet fully adapted to student life.

The sociological toolkit of the questionnaire survey to identify the degree of adaptation of the student to the educational activities and the student group included test methods of diagnosis of socio-psychological adaptation of K. Rogers and R. Diamond.

The reliability of the obtained results was checked using the "splitting" method and the subsequent calculation of the corresponding coefficients. In order to determine accuracy and reliability on two scales, the Rylon formula was used; the Spearman-Brown formula and the Cronbach formula were used to calculate the reliability-coordination coefficients. According to the results of the calculations, all the obtained parameters were in the range of $0.90-0.92$.

The adaptation coefficient of the surveyed students to the study group was $K_{1}=12.07(0.75)$, which indicates a level above the average on the scale of adaptation to the study group. This indicator shows that more than half of the respondents feel comfortable in the student group, communication processes with classmates are easy, follow the rules and norms of behavior accepted in the group. However, there are almost half of the students who experience certain difficulties in communicating with their classmates. Such students show some difficulties in relations with their classmates.

The coefficient of adaptation of students to the educational process was $K_{2}=10.12$ (0.63). This indicator shows that almost half of the surveyed students have various difficulties in mastering subjects and performing academic tasks; they have certain difficulties in public speaking at classes, in expressing their thoughts. In the process of studying the material, they are not able to ask the teachers any clarifying questions in public.

The analysis of students' emotional state in the course of educational activity was made on the basis of the following questions: "Are you experiencing tension, anxiety while you are at the university? If "YES", what does it have to do with?"; "What are your feelings before the session?", "What do you care most about now? At the same time, we were interested in the position of students on the eve of the session. The survey results showed that $44.5 \%$ of students "feel insecure about themselves and their knowledge" before the session. $39.8 \%$ of the students "have a normal attitude to passing the session, without much excitement. $15.7 \%$ of respondents answered that they "did not think about it at all". What kind of problems are the students most concerned about? We received the following answers: $60.8 \%$ of students name "problems with education"; 16.3\% "problems with housing"; 9.6\% of respondents "have difficulties with the library"; $8.1 \%$ of respondents "have difficulties in relationships with classmates, roommates"; $5.2 \%$ of students "have problems in relationships with parents". 
Difficulties with learning, mentioned by almost $61 \%$ of respondents, have quite real reasons, understood by all respondents. According to $37.0 \%$ of students, the main cause of problems "lies in their own laziness"; $20.4 \%$ mention "weak school base",17.0\% of students noted "poor memory" as the reasons; $15.7 \%$ mention "low concentration of attention". Students who answered that the reason for learning problems is their "poor health" (9,9\%) should be paid attention to.

The identified problems of adaptation to the learning process have shown that in many disciplines students need additional correctional courses or consultations, as they are not always able to prove themselves in the classroom. The obtained results indicate the need for a more attentive attitude of faculty, curators of student groups, parents to the need to adjust the level of adaptation of students to educational activities.

The role of the supervisor of the student group in the process of adaptation of students is quite important. This is also indicated by the students themselves. So, to the question: "Does the supervisor help you in the organization of the educational process and life of the group?" the positive answer was given by $78.2 \%$ of the surveyed students, $18.0 \%$ of respondents said that "Sometimes", only $3.8 \%$ of students gave a negative answer.

Parents are a rather active factor influencing the adaptation process of students, as their influence at this age is still relatively high. It is to parents that $48.2 \%$ of the surveyed students ask for help and advice when problems arise. At the same time, friends and acquaintances are a significant factor in solving life problems for $21.0 \%$ of respondents. $11.8 \%$ of respondents turn to the curator for help. And only a psychologist, in case of problems, will be addressed by $0.9 \%$ of the surveyed students. Meanwhile, there is a group of students (18.1\%), which does not ask for help and advice from anybody in case of difficulties. From our point of view, this category of students requires special attention from the curator and teachers, as it may constitute a "risk group".

Average statistical coefficients for the above indicators of adaptability are shown in Table 1 . This table shows that the most problematic indicators for adaptation of students are: peculiarities of emotional state of first-year students $(\mathrm{K}=0.36)$ and satisfaction with learning activities $(\mathrm{K}=0.48)$. The least problematic for freshmen were: adaptation of students to the student group $(\mathrm{K}=0.75)$ and motivational orientation of education ( $\mathrm{K}=0.67)$. This is explained by the purposeful choice of the university students and the direction of training, as well as sufficient resources for communication in the student group.

\section{Figures and tables}

The analysis of the problems of adaptation of bachelor students of pedagogical field to the conditions of training in an agrarian university allows to characterize the general level of adaptation as an average $(\mathrm{K}=0.58)$. The most problematic components are: the emotional state of students and satisfaction with learning activities, which requires a comprehensive work of curators of student groups, psychological and pedagogical service of the university to correct the level of adaptation of students to learning activities. The results of the research are presented in Table I.
Table I: Summary indicators of adaptation of students of pedagogical field in Federal State Budgetary Educational Institution of Higher Education Belgorod State Agricultural Univerisity named after V. Gorin.

\begin{tabular}{|l|c|}
\hline \multicolumn{1}{|c|}{ Indicators } & Coefficients \\
\hline Satisfaction with educational activities & 0.48 \\
\hline Motivation level & 0.67 \\
\hline Emotional state peculiarities & 0.36 \\
\hline Student adaptation to learning activities & 0.63 \\
\hline The student's adaptation to the group & 0.75 \\
\hline Total & $\mathbf{0 . 5 8}$ \\
\hline
\end{tabular}

\section{RECOMMENDAITONS}

To further improve the process of adaptation of bachelor students in the university, we have developed the following practical recommendations: the design and implementation of the system of intensive adaptation of students in the educational process based on the creation of the "Center for support of adaptation of freshmen students", the development and implementation of the technology of the curator, aimed at the process of adaptation and conscious professional choice of students, the creation of the necessary organizational and psychological and pedagogical conditions for the successful adaptation of the students

The pedagogical impact should be strictly defined by the individual characteristics and capabilities of the student. Teachers and tutors can use the following practical materials to carry out their work in these areas: a questionnaire "Life goals", an exercise "Image of the future", a method of diagnosing the degree of satisfaction with basic needs, a questionnaire "What we are interested in". The results of the survey can be discussed in the form of talk shows in the course of the discipline "Introduction to professional and pedagogical activity".

The university' psychological service should systematically monitor the adaptation of students. This will allow timely identification, assessment and correction of psychological and pedagogical impacts. At the same time, it is expedient to pay closer attention to the following questions: establishment and maintenance of the social status of the student in the new team; formation of positive educational motives; prevention and removal of psychological discomfort associated with educational activities; organization of a system of social and psychological training to improve communication skills; psychological and pedagogical counseling of curators of student groups on the organization of educational work with students of "risk group".

\section{RESULTS AND DISCUSSION}

The authors have revealed general and specific features of the adaptation process of students of pedagogical orientation in the conditions of training in non-core higher education institution; comparative analysis of social-psychological and social-professional adaptation of students has been carried out; the most acute problems and difficulties of socialprofessional adaptation have been revealed;

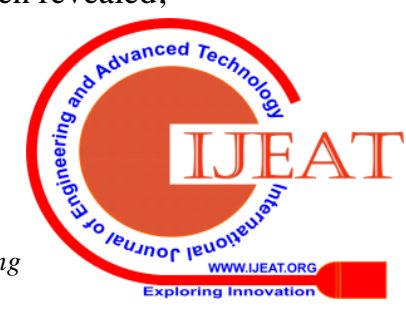


Criteria and levels of adaptation of students of pedagogical orientation have been formed; proposals on improvement of the process of adaptation of students of pedagogical orientation have been developed and applied in practice

\section{VII.CONCLUSION}

In this scientific article we have presented a study of the process of adaptation of bachelor students of pedagogical field, conducted on the basis of Federal State Budgetary Educational Institution of Higher Education Belgorod State Agricultural Univerisity named after V. Gorin, and have determined the main directions of its improvement.

In the course of the study we have studied the theoretical foundations of the adaptation process; analyzed the level of adaptation of students in the process of learning and leisure activities; formulated the main directions of work of the faculty to improve the process of adaptation of bachelor students of pedagogical field in the training activities of Federal State Budgetary Educational Institution of Higher Education Belgorod State Agricultural Univerisity named after V. Gorin. On the basis of the generalization of the results of the research, carried out both at the theoretical and empirical levels, we have identified social and pedagogical conditions that contribute to the effective process of adaptation of students in the university. The results of the identification of the level of adaptation of students of Federal State Budgetary Educational Institution of Higher Education Belgorod State Agricultural Univerisity named after V. Gorin indicated a number of problems indicating an insufficient level of management of the process of adaptation of bachelor students of pedagogical field in this university. The most problematic components of adaptation turned out to be: emotional state of students and satisfaction with educational activities. Respondents noted that the most important people they tend to turn to for help are, first of all, parents, then friends. The third place is occupied by mentors, and only a small percentage of students (less than one percent) go to a psychologist in difficult moments.

Monitoring of the process of adaptation of students allowed to draw conclusions about the need for comprehensive work of curators of student groups, psychological and pedagogical service of the university on correction of the level of adaptation of students to the educational process. As the basic directions of improvement of the system of adaptation of students by pedagogical professions in Federal State Budgetary Educational Institution of Higher Education Belgorod State Agricultural Univerisity named after V. Gorin, we offer the following measures:

- Creation and introduction of a system of intensive adaptation of freshmen into the educational process of the university. In order to achieve this goal, it is necessary to create a "Center for support of adaptation of freshmen students";

- Detailed elaboration and implementation of the curator's activity technology in the educational process of the university, aimed at ensuring adaptation and conscious professional choice of freshmen of the future pedagogical specialty;

- Creation of conditions for information and organizational adaptation of students to the new environment, the structure of the university, its requirements and responsibilities;

- Creation of psychological and pedagogical conditions for the internal integration of groups of freshmen of the pedagogical direction of training with students of other courses and faculties of the university. The solution to the problem of social adaptation of students in a professional educational organization is possible through the management of this process in higher education.

\section{REFERENCES}

1. Amponsah, M.O. Non UK University students stress levels and theircoping strategies. Educational Research. - 2010(4). - p. 88-99. URL:

https://www.researchgate.net/publication/228354692_Non_UK_Univ ersity_students_stress_levels_and_their_coping_Strategies

2. Bennett N.J., Kadfak A., Dearden P. Community-based scenario planning: a process for vulnerability analysis and adaptation planning to social-ecological change in coastal communities // Environment, Development and Sustainability. - 2016. - Vol. 18 (6). - P. 17711799. DOI: http://dx.doi.org/10.1007/s10668-015-9707-1

3. Byrne B.M. Structural equation Modeling With AMos: Basic concepts, Applications and Program-ming. 2nd ed. (Multivariate applications series). - New York: Taylor \& Francis Group, 2010.

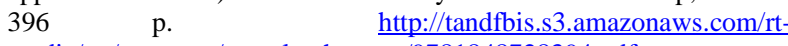
media/pp/common/sample-chapters/9781848728394.pdf

4. Dombrovskis V., Guseva S., \& Murasovs V. Motivation to Work and the Syndrome of Professional Burnout among Teachers in Latvia. Procedia -Social and Behavioral Sciences. - 2011. - №29. - P.98 -106. URL:

https://www.researchgate.net/publication/257714919_Motivation to work and the syndrome of professional burnout_among_teachers_in_Latvia

5. Grant K E, Compas B E, Thurm A E, et al. Stressors and child and adolescent psychopathology: Measurement issues and prospective effects. Journal of Clinical Child and Adolescent Psychology. - 2004 - 33(2). - $\quad$ P. 412-425. URL: https://www.researchgate.net/publication/8570087_Stressors_and_Ch ild_and_Adolescent_Psychopathology_Measurement_Issues_and_Pro spective_Effects

6. Hassan K., Adhami N. Adaptation and Validation of the Children's Anger Response Checklist for Grades 4-6 Lebanese Students // Child Indicators Research. - 2016. - Vol. 9 (4). - P. 985-1002. DOI: http://dx.doi.org/10.1007/s12187-015-9352-0

7. Lobbestael J., Cima M., Lemmens A. The relationship between personality disorder traits and reactive versus proactive motivation for aggression // Psychiatry Research. - 2015. - Vol. 229, Issue 1-2. - P 155-160. DOI: http://dx.doi.org/10.1016/j.psychres.2015.07.052

8. Markus H. R., Nurius P. Possible selves // American psychologist. 1986. - Vol. 41, Issue 9. - P. 954-969. DOI: https://doi.org/10.1037/0003-066x.41.9.954

9. Richardson M., Abraham C., Bond R. Psychological correlates of university students academic performance: a systematic review and meta-analysis // Psychological Bulletin. - 2012. - Vol. 138 (2). - P. 353-387. DOI: http://dx.doi.org/10.1037/a0026838

10. Rockenbach A. B., Mayhew M. J. The campus spiritual climate: Predictors of satisfaction among students with diverse worldviews // Journal of College Student Development. - 2014. - Vol. 55 (1). - P. 41-62. DOI: http://dx.doi.org/10.1353/csd.2014.0002

11. Aleksandrov E. P., Vorontsova M. V. Problems of adaptation of students to the educational environment of the university and the profession // Современные проблемы науки и образования.(Modern Problems of Science and Education) - 2014. No. 5. - P. 111-111. URL: https://elibrary.ru/item.asp?id=22566444

12. Anisimova T.G. Система управления адаптацией студентов в вузе (The system of management of adaptation of students in the university )// Социология образования.(Sociology of Education) 2014. $\quad-\quad$ No. $12 . \quad-\quad$ P. $101-108$ URL: https://elibrary.ru/item.asp?id=22561873

13. Bondar' E.A., Nikulina N.N., Mel'nikova O.V. Socio-psychological aspects of adaptation management for first-year students of Belgorod State Agrarian University // Molodezh' XXI veka: aktual'nye problemy vospitaniya v sovremennykh usloviyakh: mezhdunarodnaya nauchno-prakticheskaya konferentsiya (Youth of the XXI Century: Topical Problems of Education in Modern Conditions: International Scientific and Practical Conference). - Kursk: Kurskaya gosudarstvennaya sel'skokhozyaystvennaya akademiya im. professora I.I. Ivanova, 2016. P. 47-54. URL:

https://elibrary.ru/item.asp?id=25 $\underline{812538}$ 
14. Bondar' E.A., Nikulina N.N., Trunova V.D. Management of the process of social and psychological adaptation of agrarian university students // Upravlenie v XXI veke: materialy mezhdunarodnoy nauchno-prakticheskoy konferentsii (Management in the XXI Century: Materials of the International Scientific and Practical Conference). Belgorod: ID «Belgorod» publ., 2015. - P. 139-144. URL:

http://dspace.bsu.edu.ru/bitstream/123456789/20630/1/Upravlenie_X XI_Vek_Prepod_2015.pdf

15. Galstyan A. G., Minasyan S.M. No. 4 (104). - P. 97-101. URL: https://elibrary.ru/item.asp?id=24141791

16. Gordienko I.V. Activity of the supervisor of the student group on formation of social and professional adaptation of university students in the conditions of organic unity of education, upbringing and socialization // Kul'turnaya zhizn' Yuga Rossii (Cultural Life of Southern Russia). - 2010. - No. 1. - P. 107-109 URL: https://rucont.ru/efd/145653

17. Gordienko I.V. Pedagogical conditions for preparing graduates for future social and professional activities // Innovatsii v APK: problemy i perspektivy (Innovations in the Agribusiness Sector: Problems and Prospects.) - 2015. - No.3 (7). - P. 40-43. URL: https://rucont.ru/efd/568939

18. Davityan M.G, El'nikova G.A., Revenko N.V. Family in a risky and unstable society // Kazanskaya nauka (Science of Kazan). 2015. - No. 6. - $\quad$ P. 293-295. URL:

19. Davityan M.G., Kutin D.D. Legal regulation of relations in the field of education // Gorinskie chteniya. Nauka molodykh innovatsionnomu razvitiyu APK: mezhdunarodnaya studencheskaya nauchnaya konferentsiya (Gorin readings. Science of young people innovative development of agro-industrial complex: international student scientific conference). - Mayskiy: FGBOU VO Belgorodskiy GAU, 2019.2 - $250 . \quad$ URL: http://www.bsaa.edu.ru/upload/2018/konferencii/gorinskie_chteniya 1.pdf

20. Davityan M.G., Ryadinskiy L.P. State family policy as a factor in the formation of family strategies for young people // Проблемы и перспективы инновационного развития агротехнологий: Problemy i perspektivy innovatsionnogo razvitiya agrotekhnologiy: materialy KhKh Mezhdunarodnoy nauchno-proizvodstvennoy konferentsii (Problems and Prospects of Innovative Development of Agricultural Technologies: Proceedings of the XX International Scientific and Production Conference). - 2016.- P. 194-195. URL: https://elibrary.ru/item.asp?id=26143743

21. Zhuina D. V., Koroleva N. Р. Особенности психологической адаптации $\mathrm{K}$ условиям обучения в вузе студентовпервокурсников (Peculiarities of psychological adaptation to the conditions of study at the university of freshmen)// Актуальные проблемы и перспективы развития современной психологии. Aktual'nye problemy i perspektivy razvitiya sovremennoy psikhologii. (Actual Problems and Prospects of Modern Psychology Development). - $2013 . \quad-\quad$ No.1. - P. 51-54. URL: https://elibrary.ru/item.asp?id=22954195

22. Zakharov N.N., Antip'ev A.G., Alikina O.A., Kopytova S.I., Kulyapin A.S., Travnikov G.N. Sotsiologicheskiy monitoring proforientatsii, predprofil'noy podgotovki i profil'nogo obucheniya. Monografiya (Sociological Monitoring of Career Guidance, Pre-profile Preparation and Proficiency Training. Monograph). - Perm': NOU SOSh Evropeyskaya shkola «Ex professo» s uglublennym izucheniem sotsial'no-gumanitarnykh predmetov» publ., 2004. - 158 p. URL: https://docplayer.ru/27298311-Sociologicheskiy-monitoringproforientacii-predprofilnoy-podgotovki-i-profilnogoobucheniya.html

23. Isaev I.F. Deyatel'nost' kuratora studencheskoy gruppy: lichnostnoorientirovannyy podkhod (Student Group Supervisor's Activities: A Personally Focused Approach) / I.F. Isaev, Eroshenkova E.I. //Vysshee obrazovanie v Rossii (Higher Education in Russia).- 2009. $\begin{array}{llll}\text { No. } & \text { 6.- } & \text { P. } & 149-152\end{array}$ URL: https://cyberleninka.ru/article/n/deyatelnost-kuratorastudencheskoy-gruppy-lichnostno-orientirovannyy-podhod

24. Krikun E.V. Belozerova I.A. Psychological types of personality and their adaptation to student life // Metodika prepodavaniya psikhologicheskikh distsiplin v sovremennom universitete: materialy mezhdunarodnoy nauchno-prakticheskoy i nauchno-metodicheskoy konferentsii professorsko-prepodavatel'skogo sostava i aspirantov (5 aprelya 2017 g. - 5 aprelya 2018 g.) (Methods of Teaching Psychological Disciplines at the Modern University: Materials of the International Scientific-Practical and Scientific-Methodical Conference of Faculty and Postgraduate Students (April 5, 2017 https://elibrary.ru/item.asp?id=23873856

April 5, 2018). - Belgorod: BUKEP publ., 2017. - P. 64-71. URL: https://elibrary.ru/item.asp?id=35294378

a. Krikun E.V. Belozerova I.A. Psychological portrait of a person in the conditions of adaptation to student life // Psikhologicheskie znaniya v sovremennom mire: Mezhdunarodnaya nauchno-prakticheskoy i nauchno-metodicheskoy konferentsii professorskoprepodavatel'skogo sostava i aspirantov (7 aprelya 2016 goda) (Psychological Knowledge in the Modern World: International Scientific-Practical and Scientific-Methodological Conference of Faculty and Postgraduate Students (April 7, 2016). - Belgorod: BUKEP publ., 2016. - P.145-152. URL: https://elibrary.ru/item.asp?id=27612785

25. Krikun E.V. Belozerova I.A. Self-assessment of character and analysis of adaptation processes in freshmen [Electronic resource] $/ /$ Politematicheskiy setevoy elektronnyy nauchnyy zhurnal Kubanskogo gosudarstvennogo agrarnogo universiteta (Nauchnyy zhurnal KubGAU) (Polythematic Networked Electronic Scientific Journal of the Kuban State Agrarian University (Scientific Journal of Kuban State Agrarian University). - 2016. - No. 03(117). - P. 912 - 925. URL: http://ej.kubagro.ru/2016/03/pdf/59.pdf

26. Lakhtin A.Yu. Teoreticheskie osnovy problemy adaptatsii studentov $\mathrm{k}$ obucheniyu v Vuze sredstvami fizicheskoy kul'tury (Theoretical bases of the problem of adaptation of students to the teaching of the University by means of physical education). - Biysk: Altayskiy gosudarstvennyy tekhnicheskiy universitet im. I.I. Polzunova, 2014 - 81p. URL: http://irbis.bti.secna.ru/doc4/2014-25.pdf

27. Lyubimova N.I. Pedagogical interaction as a tool for socialization of students // Problemy sotsializatsii i individualizatsii v obrazovatel'nom prostranstve. Chast' 2: Mezhdunarodnaya nauchnoprakticheskaya konferentsiya (Belgorod, 22-23 noyabrya 2018 goda) (Problems of Socialization and Individualization in Educational Space. Part 2: International Scientific and Practical Conference (Belgorod, 22-23 November 2018). - Belgorod: ID «Belgorod» NIU «BelGU» publ., 2018. - P. 168-171. URL: http://dspace.bsu.edu.ru/bitstream/123456789/24547/1/Problemy_Sot sializatsii 2 18.pdf

28. Lyubimova N.I. Formation of experience of pedagogical interaction in the future teachers of the secondary vocational education system // Nauchnye vedomosti Belgorodskogo gosudarstvennogo universiteta. Gumanitarnye nauki (Scientific Bulletins of Belgorod State University. Humanities). - 2018g. - No. 2. - Volume 37 - P.312-320. URL:

http://dspace.bsu.edu.ru/bitstream/123456789/24896/1/Lyubimova_F ormirovanie.pdf

29. Lyubimova N.I., Gordienko I.V., Shevchenko S.N. Axiological problems in the educational work of professional educational organizations to shape the worldview of future specialists // Nauchnyy zhurnal. Filosofiya obrazovaniya (A Science Journal. Philosophy of Education.) - 2017. - No. 2 (71). - P.52-57. https://www.sibran.ru/journals/issue.php?ID=170594\&ARTICLE_ID $=170608$

30. Pryazhnikov N.S. Professional'noe samoopredelenie: teoriya i praktika: ucheb. posobie dlya stud. vyssh. ucheb. zavedeniy (Professional Self-Determination: Theory and Practice: A Manual for Students in Higher Education)/ N.S. Pryazhnikov. - M.: Izdatel'skiy tsentr «Akademiya» publ., $2008 . \quad-320$ p. URL http://psychlib.ru/mgppu/PPs-2008/PPs-320.htm\#\$p1

31. Romm M.V., Romm T.A. Socialization and professional education in higher education // Vysshee obrazovanie v Rossii (Higher Education in Russia). - 2010. - No.10. - P. 104-114: URL: https://cyberleninka.ru/article/n/sotsializatsiya-i-professionalnoevospitanie-v-vysshey-shkole

32. Rostovtseva M.V. Adaptation and socialization: general and special analysis // Sotsiodinamika (Sociodynamics). - 2016. - No. 7. - P. 31 37. DOI: 10.7256/2409-7144.2016.7.18114 URL: https://nbpublish.com/library_read_article.php?id=18114

33. Svechnikova Yu.A. Adaptation as a social category [Electronic resource] // Molodoy uchenyy. (Young Scientist). - 2019. - No. 8 (246). - P. 155-157. URL: https://moluch.ru/archive/246/56783/

34. Sedin V.I., Leonova E.V. Student adaptation to university studies: psychological aspects // Vysshee obrazovanie v Rossii (Higher Education in Russia). - 2009. - No. 7. - P. 83-89. URL: https://elibrary.ru/item.asp?id=12800687 
35. Khanyukova A.S., Nikulina N.N. Adaptation of freshmen to social and pedagogical environment in higher education institutions // Materialy Mezhdunarodnoy studencheskoy nauchnoy konferentsii. Mayskiy: FGBOU VO Belgorodskiy GAU, 2016 (Materials of the International Student Scientific Conference. May: Federal State Budgetary Educational Institution of Higher Education Belgorod State Univerisity). - P. 197. https://elibrary.ru/item.asp?id=26594037

36. Khaustova A. I. Socio-psychological adaptation [Electronic resource] // Molodoy uchenyy. (Young Scientist). - 2016. - No. 26. - P. 614617. URL: https://moluch.ru/archive/130/36005/

\section{AUTHOR'S PROFILE}

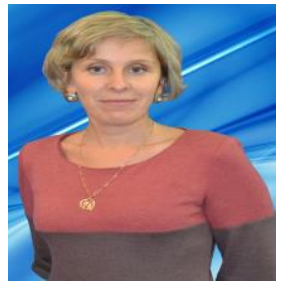

Nikulina Natal'ya Nikolaevna - $\mathrm{PhD}$ in Pedagogical Sciences, Associate Professor. Higher education. Graduated from Belgorod State Pedagogical University in 1995 with a degree of a Primary School Teacher. Head of the Department of Professional Education and Social and Pedagogical Disciplines, Associate Professor of the Department of Professional Education and Social and Pedagogical Disciplines, Federal State Budgetary Educational Institution of Higher Education Belgorod State Agricultural Univerisity. The total number of publications is 162 .

E-mail: nikulina nn@bsaa.edu.ru

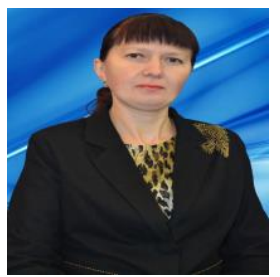

Gordienko Irina Vladimirovna - $\mathrm{PhD}$ in Pedagogical Sciences, Associate Professor. Higher education. In 1999, she graduated from Belgorod State University with a degree in History and Social and Political Science. Associate Professor of the Department of Professional Education and Social and Pedagogical Disciplines, Federal State Budgetary Educational Institution of Higher Education Belgorod State Agricultural Univerisity. The total number of publications is 115.

E-mail: girina@mail.ru

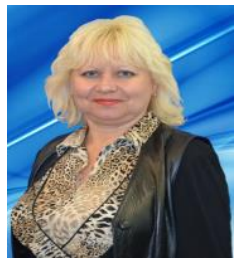

Belozerova Irina Aleksandrovna - $\mathrm{PhD}$ in Philosophy, Associate Professor.

Higher education. In 1989 she graduated from Kharkiv State University with a degree in Biology, Teaching Biology and Chemistry. In 2018, she underwent professional retraining and was qualified as a "Philosophy Teacher". Associate Professor of the Department of Professional Education and Social and Pedagogical Disciplines, Federal State Budgetary Educational Institution of Higher Education Belgorod State Agricultural Univerisity. The total number of publications is 98 .

E-mail: irina_belozerova1965@mail.ru

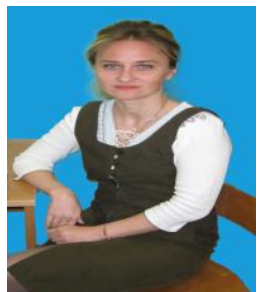

Lyubimova Natal'ya Ivanovna - $\mathrm{PhD}$ in Pedagogical Sciences.

Higher education. In 2002, she graduated from Belgorod State University with a degree of a Primary School Teacher. Associate Professor of the Department of Professional Education and Social and Pedagogical Disciplines, Federal State Budgetary Educational Institution of Higher Education Belgorod State Agricultural Univerisity. The total number of publications is 65 .

E-mail: lybimova.1979@mail.ru

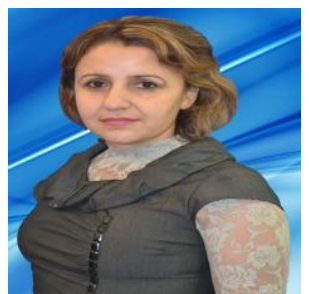

Davityan Manushak Galustovna - $\mathrm{PhD}$ in Sociological Sciences.

Higher education. In 1999, she graduated from Belgorod University of Consumer Cooperatives with a degree in Law. Associate Professor of the Department of Professional Education and Social and Pedagogical Disciplines, Federal State Budgetary Educational Institution of Higher Education Belgorod State Agricultural Univerisity. The total number of publications is 74.E-mail: 79611729056@yandex.ru 